J. Clin. Chem. Clin. Biochem.

Vol. 18, 1980, pp. 149-155

\title{
Influence of Turbidity on Photometric Assays: A Blank Sample Must Always Be Used
}

By G. Hubsch, O. Houot and J. Henny

Laboratoire du Centre de Médecine Préventive (Directeur: Prof. G. Siest), 2, avenue du Doyen Jacques Parisot, 54500 Vandoeuvre-lès-Nancy, France

(Received January $31 /$ July 31,1979$)$

Summary: The authors studied the influence of sample turbidity on photometric assays at different wavelengths. Turbidity was created by using a mixture of hydrazine sulfate and hexamethylene tetramine, and a dye solution ( $p$-nitrophenol, cobalt nitrate).

This work demonstrates the necessity of using a blank sample, for example in the glucose assay (glucose oxidase/ peroxidase). The influence of turbidity on an assay depends upon the instrument. Knowledge of this influence is essential for the evaluation of the viablity of an assay in hyperlipemic serum.

\section{Einfluß der Trübung auf photometrische Bestimmungen: Muß jeweils ein Proben-Leerwert benutzt werden?}

Zusammenfassung: Die Autoren untersuchten den Einfluß der Trübung von Proben auf photometrische Bestimmungen bei verschiedenen Wellenlängen. Die Trübung wurde bewirkt mit Hilfe einer Mischung von Hydrazinsulfat und Hexame thylentetramin und einer Farblösung ( $p$-Nitrophenol, Cobaltnitrat).

Diese Arbeit berichtet über die Notwendigkeit, einen Probenleerwert zu benutzen, z. B. bei der Glucosebestimmung (Glucoseoxidase/Peroxidase-Methode). Der Einfluß der Trübung auf eine Bestimmung ist bei den verschiedenen Instrumenten unterschiedlich. Die Kenntnis dieses Einflusses ist unentbehrlich für die Bewertung der Durchführbarkeit einer Bestimmung bei hyperlipämischem Serum.

\section{Introduction}

With the development of direct methods (without deproteinisation) $(1-2)$ it is necessäry to emphasize the importance of the "blank sample" (i.e. the sample containing plasma and buffer) particularly for lipemic sera or plasmas. Does turbidity affect the result of an assay? Is the use of a blank sample indispensable, and is it sufficient to correct. for this effect? These questions are examined here, using the wavelengths normally used in the laboratory.

Figure 1 shows the frequencies of various turbidity assay values found for presumably healthy individuals undergoing medical checkups at the "Centre de Médecine Préventive" in Nancy.

Fifty per cent of the population of the individuals had not fasted; $2.5 \%$ of those who had fasted had turbidities greater than 0.4 absorbance units. Eleven per cent of the population that had not fasted had high turbidities, i.e. greater than 0.7 absorbance units. The problem presented by the consequences and the frequency of turbidity should be considered for any new method and for any instrument $(6,9)$.

\begin{tabular}{|c|c|c|c|c|}
\hline $97.5 \%$ & $2.4 \%$ & $0.1 \%$ & $<0.1 \%$ & Fasting population \\
\hline & & & & $\begin{array}{l}\text { Turbidity } \\
\text { (absorbance units) }\end{array}$ \\
\hline $50 \%$ & $38 \%$ & $11 \%$ & $1 \%$ & $\begin{array}{l}\text { Non-fasting } \\
\text { population }\end{array}$ \\
\hline
\end{tabular}

Fig. 1. Turbidity distribution of the plasma samples.

\section{Materials and Methods}

Turbidity was determined with a GSA II Greiner (3) by diluting $20 \mu 1$ of the sample in $400 \mu \mathrm{l}$ of $\mathrm{NaCl}$ and $\mathrm{NaF}$ solution. The respective concentration of these reagents in the final volume was 0.118 and $0.02 \mathrm{~mol} / \mathrm{l}$.

Zero was established with $\mathrm{NaCl}$ solution, using $578 \mathrm{~nm}$. When the wavelength is increased (i.e. to avoid interference by bilirubin and hemoglobin), the light transmission of a turbid solution is decreased. The results are expressed in absorbance units.

The tests were performed by adding a turbid reference solution to a dye solution of known absorbance, and measuring the effect at a given wavelength.

\section{Apparatus}

The Aminc $\mathrm{DW}_{2}$ spectrophotometer (fig. 2b) is a high performance tungsten lamp instrument. It facilitates the absorbance 


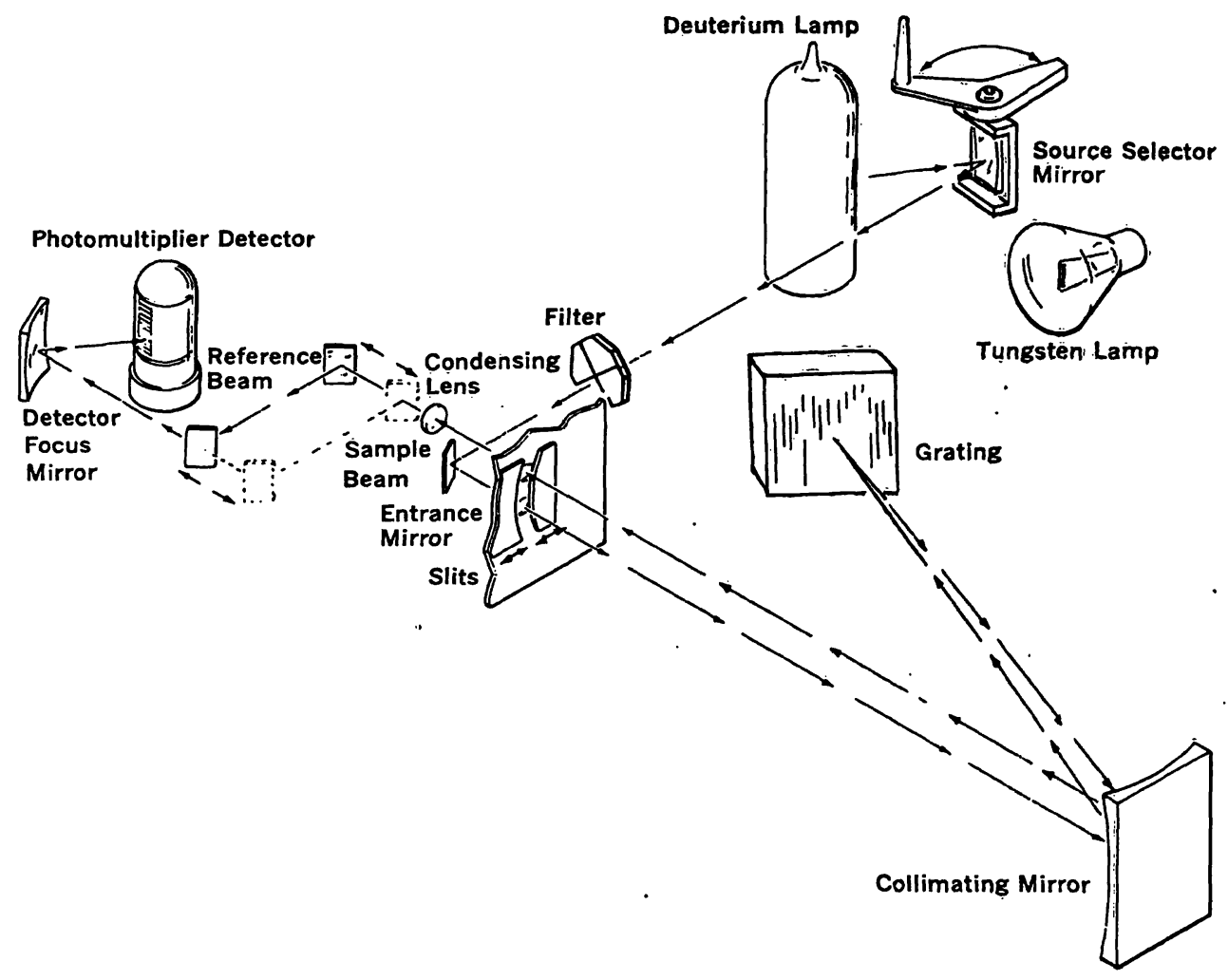

Fig. 2a

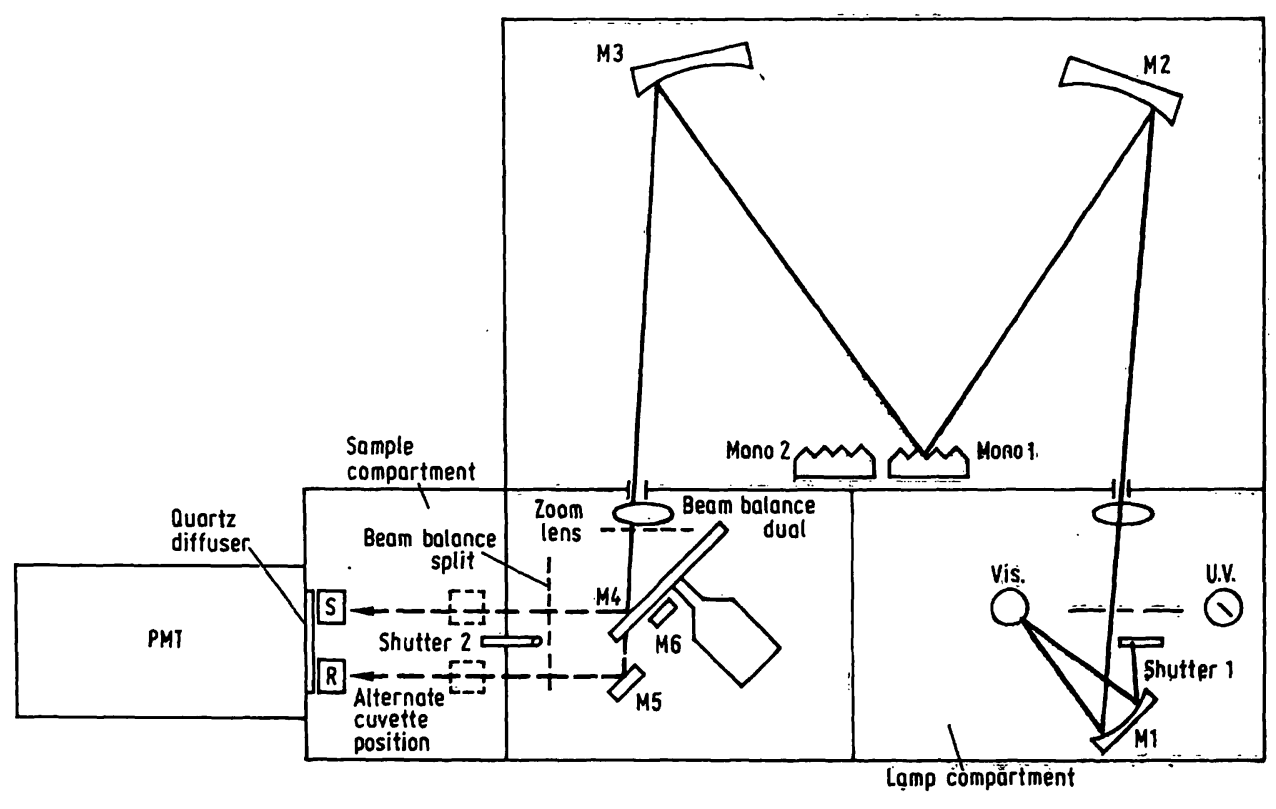

Fig. 2b

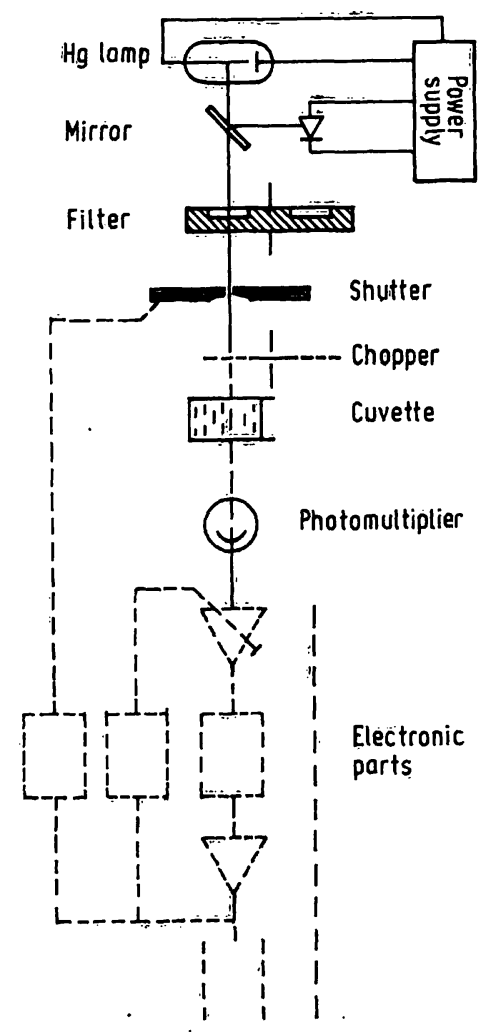

Fig. 2c
Fig. 2. Optical arrangements of the spectrophotometers used.

Fig. 2a. Beckman DB GT
Fig. 2b.Aminco DW $2: P M \bar{T}$ (phòtómultiplier)
Fig. 2c. Greiner GSA II 
reading in a turbid medium by permitting the photomultiplier to be positioned $0.5 \mathrm{~cm}$ from the cuvette. This spectrophotometer served as the control for all the tests carried out in this work, and it was used to plot the absorbance spectrum as a function of wavelength for each of the various mixtures used. Figure 3 shows an example of two spectra. The control curve is drawn to assure that the addition of the turbid solution does not provoke a displacement of the absorption peak of the coloured solution.

Two other instruments used: the Greiner GSA II photometer (fig. 2c) with an interference filter and a mercury vapor lamp from an automatic device; and the Beckman DB GT spectrophotometer (fig. 2a) which has a hydrogen lamp and a tungsten lamp, and wavelength selection by a diffraction grating ${ }^{1}$ ).

\section{Experimental method}

\section{Reagents}

For the studies at $366 \mathrm{~nm}$, potassium dichromate dye solution (340 $\mu \mathrm{mol} / 1$ in $1 \mathrm{mmol} / 1$ perchloric acid) was used (7-9-14).

For the studies at $405 \mathrm{~nm}, p$-nitrophenol $(60 \mu \mathrm{mol} / \mathrm{l})$ in an alkaline solution $(20 \mathrm{mmol} / \mathrm{l})$ was used.

For the studies at $436-492-546 \mathrm{~nm}$, cobalt nitrate $(680 \mathrm{mmol} / \mathrm{l})$ in $100 \mathrm{~g} / \mathrm{kg} \mathrm{HNO}_{3}$ was used for the three wavelengths.

For the studies at $578 \mathrm{~nm}$, an iron-ferrozine mixture $(70 \mu \mathrm{mol} / 1$ of ferrous iron in $6.8 \mu \mathrm{mol} / 1$ ferrozine solution) was used.

All these reagents were used undiluted, or diluted $1 / 2,1 / 3$, or $1 / 4$ in bidistilled water, in order to achieve an appropriate range of absorbance: 1.6, 0.8, 0.4, 0.2 absorbance units (See an example tab. 1). For the turbid solution equal volumes of hydrazine sulfate $(70 \mathrm{mmol} / \mathrm{l})$ and hexamethylene tetramine $(0.7 \mathrm{~mol} / \mathrm{l})$ were mixed at the ambient temperature and allowed to stand for 24 hours (8).

The suspension is stable for one month. The original solution is used und iluted, or diluted $(1 / 4,1 / 8,1 / 16)$; as appropriate. Using the Greiner, these solutions gave turbidity values of $5.3,1.4,0.7$ 0.3 absorbance units. The dilutions were chosen to give values in the same range as those of the patients' samples. N.B. It is necessary during the assay to keep the solution continually agitated.

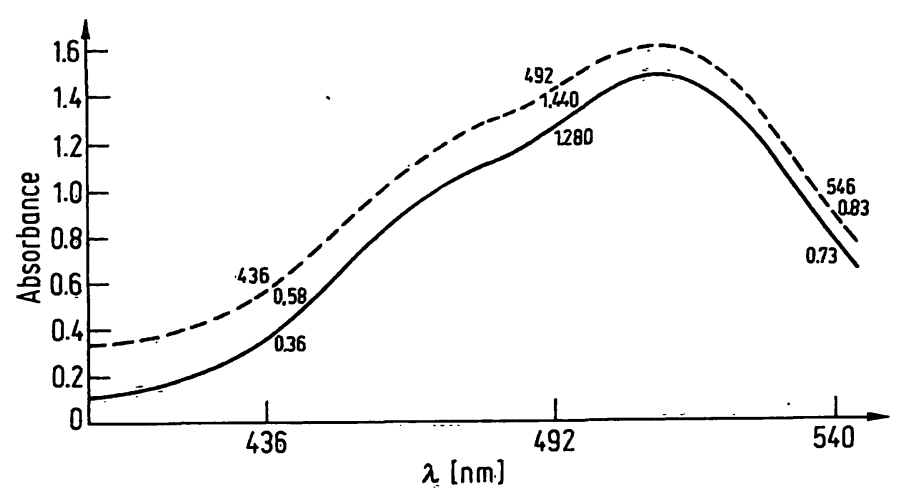

Fig. 3. Spectra are traced on the Aminco $\mathrm{DW}_{2}$ spectrophotometer.

- - - dye sọlution + initiạl turbid solution

- dye solution $+\dot{\mathrm{H}}_{2} \mathrm{O}$

1) Beckman DB GT Instruments Finance, Chemin des Bourdons, F 993220 Gagny,

DW, Aminco Kontron, 6 rue des Frères Caudron, F-78140

Velizy-Villacoublay,

GSA II Greiner, Gaswerkstraße, CH-4900 Langenthal, Schweiz
Tab. 1. An example at $366 \mathrm{~nm}$ of experimental protocol

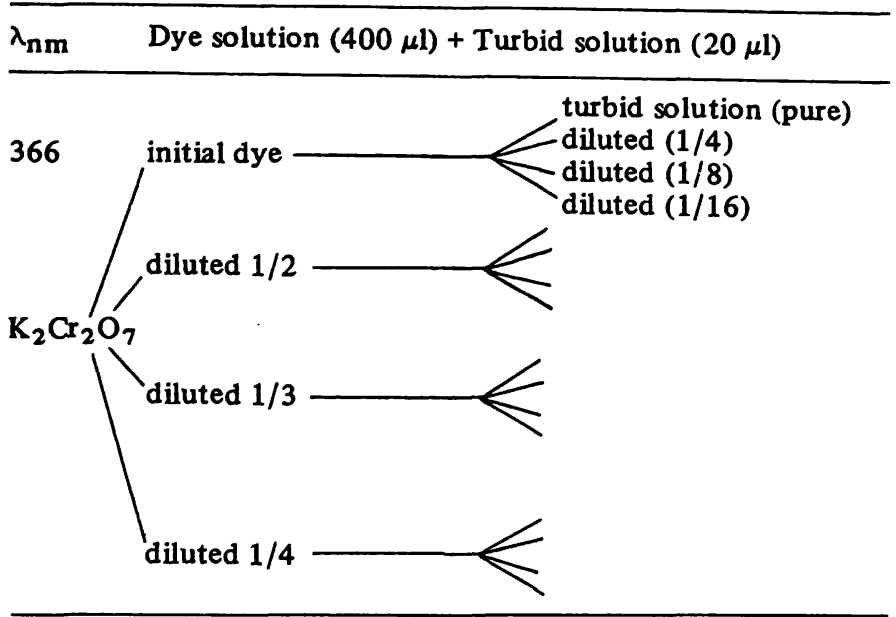

Analysis

Four tests $\mathbf{A}_{1}, \mathbf{A}_{2}, \mathbf{A}_{3}$ and $\mathbf{A}_{4}$ are represented in table 2.

$A_{1}$ corresponds to the measurement against water of the absorbance of the turbid solution (turbidity assay made on the GSA II).

A2 $_{2}$ corresponds to the measurement against water of the dye solution alone (this was the reference absorbance due to the dye).

A 3 compares the absorbance of the combined dye and turbid solutions with that of water (simulating a measurement for which a blank sample is not used)

A compares the absorbance of the combined dye and turbid solutions with that of the turbid solution (simulating a measurement for which a blank sample is used)

The influence of the turbidity was excluded by taking the difference between the absorbance obtained in $A_{3}$ and $A_{2}$; and the possible necessity of a blank sample was determined by taking the difference between $A_{4}$ and $A_{2}$. For the chosen wavelength, we used the appropriate dye solution at different dilutions as mentioned earlier. For each dilution we studied the influence of the addition of four turbid solutions, keeping the ratio turbid solution equal to the ratios sample used in the isotonic solution equal to the ratios $\overline{\text { isotonic solution }}$ turbidity measurement.

Tab. 2. Procedure method.

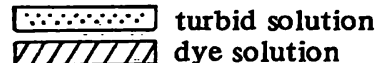

\begin{tabular}{|c|c|c|}
\hline $\begin{array}{l}\text { Measured } \\
\text { absorbance }\end{array}$ & $\begin{array}{l}\text { Test } \\
\text { absorbance }\end{array}$ & $\begin{array}{l}\text { Control } \\
\text { absorbance }\end{array}$ \\
\hline$\because \because \cdots$ & Turbid solution & Water \\
\hline $\mathbf{A}_{2}$ पाIIIIID & Dye solution & Water \\
\hline 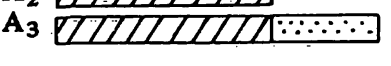 & $\begin{array}{l}\text { Dye } \\
\text { solution }\end{array}+\begin{array}{l}\text { turbid } \\
\text { solution }\end{array}$ & Water \\
\hline $\mathbf{A}_{4} \square$ & $\begin{array}{l}\text { Dye } \\
\text { solution }\end{array}+\begin{array}{l}\text { turbid } \\
\text { solution }\end{array}$ & Turbid solution \\
\hline
\end{tabular}
$\mathbf{A}_{\mathbf{3}}-\mathbf{A}_{\mathbf{2}}$
expresses the difference in absorbance due to the
$\mathbf{A}_{4}-\mathbf{A}_{2}$ turbidity
reflects the influence of the blank sample 


\section{Results}

Relationship between turbidity and concentration of the solutions

In studying whether there was a relationship between the concentration of the solutions and the magnitude of the interfering phenomenon (in this case the turbidity) we used the main absorbance region of the dye solutions. In figure 4 , the influence of the turbidity, $\mathbf{A}_{3}-\mathbf{A}_{2}$, is plotted against the absorbances of the dye solutions, $\mathbf{A}_{\mathbf{2}}$.

At $366 \mathrm{~nm}$ and perhaps at $405 \mathrm{~nm}$ a relationship appeared to exist between the turbidity and the concentration of the dye solution; at the other wavelengths, the influence of the turbidity was not linked to the value of the absorbance.

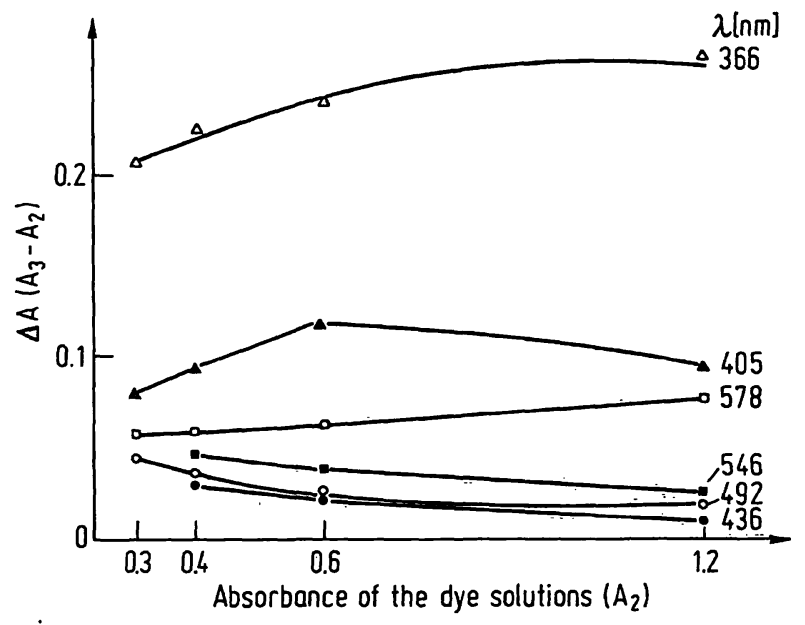

Fig. 4. GSA II - Effect of turbidity on absorbance (Turbidity $=1.4$ ) as a function of the concentration of the solution.

Difference in absorbance, $A_{\mathbf{3}}-\boldsymbol{A}_{\mathbf{2}}$, due to turbidity, as a function of wavelength

These tests were carried out in order to quantify the observed interference and to determine whether the blank sample was indispensable. It is certain that the influence of the light scattered during the course of a photometric reading is very great (3). What is measured is an apparent absorbance. One important factor is the optics of the apparatus. For this reason, we have shown the results obtained on each instrument $(4,5,6,10)$ separately.

The difference in absorbance, $A_{3}-A_{2}$, due to the addition of the turbidity, is indicated on the vertical axis in figures $5 ; 6$, and 7 . It is shown as a function of the various wavelengths for the entire range of turbid solutions.

The results obtained on the Aminco $\mathrm{DW}_{2}$ spectrophotometer (figure 5) are in agreement with those of other authors (3). They show that the absorbance due to the turbidity, $A_{3}-A_{2}$, decreased with increasing wavelength. The higher turbidity, the greater is the difference found, in particular at $366 \mathrm{~nm}$, where an $\mathrm{A}_{3}-\mathrm{A}_{2}$ value of 0.5

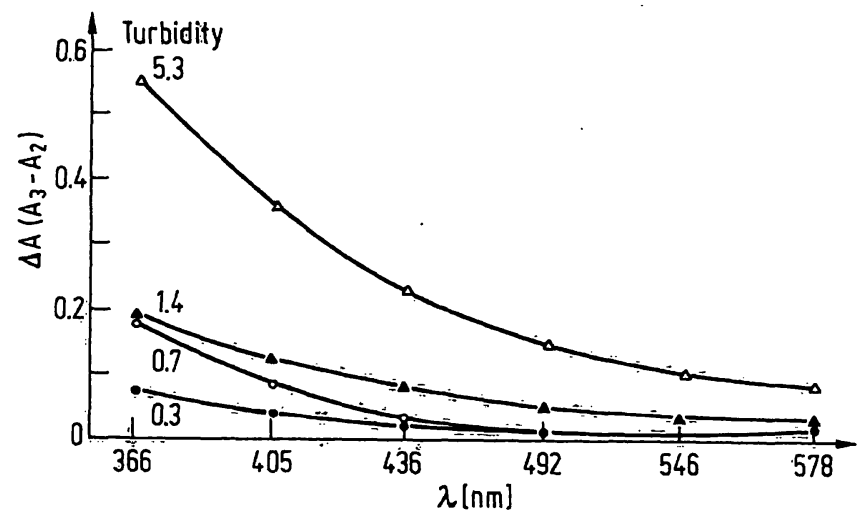

Fig. 5. Aminco $\mathrm{DW}_{2}$ - Effect of turbidity on absorbance. On the vertical axis is shown the difference in absorbance, $\mathbf{A}_{3}-\mathbf{A}_{2}$, brought about by the turbidity, as a function of wavelength.

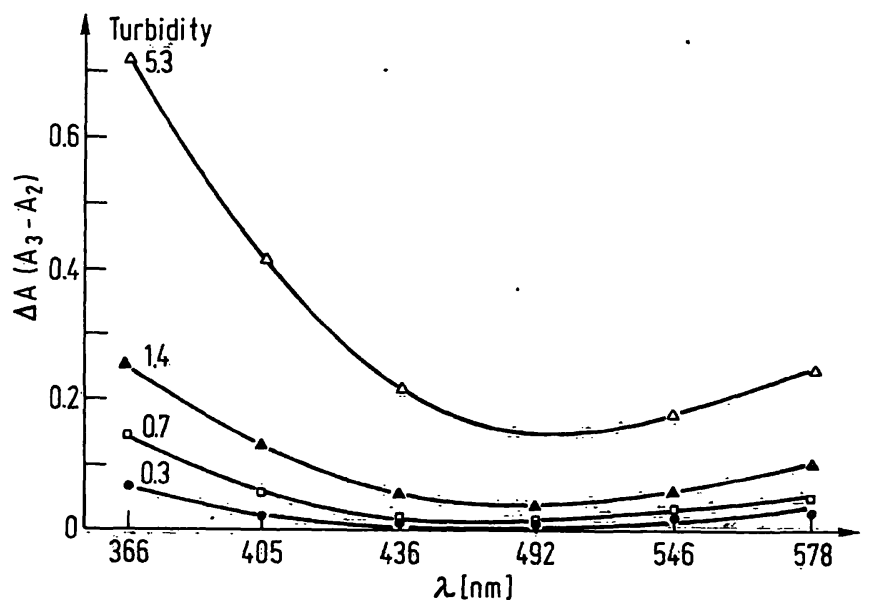

Fig. 6. Greiner GSA II - Effect of turbidity on absorbance. On the vertical axis is shown the difference in absorbance, $\mathbf{A}_{3}-\mathbf{A}_{2}$, brought about by the turbidity, as a function of wavelength.

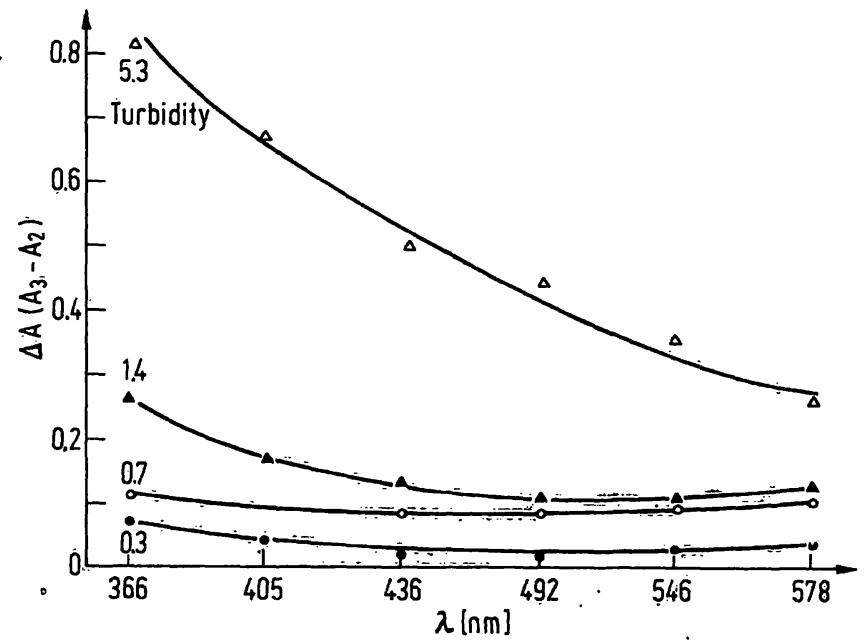

Fig. 7. Beckman DBGT - Effect of turbidity on absorbance. On the vertical axis is shown the difference in absorbance, $A_{3}-A_{2}$, brought about by the turbidity, as a function of wavelength. 
absorbance units was found for a turbidity of 5.3. The value at this wavelength is therefore too high, and it represents an error in specificity.

The values observed with the GSA II are presented in the same manner (fig. 6). Over the range of wavelengths, the results were comparable to those obtained with the Aminco $\mathrm{DW}_{2}$, except at $366 \mathrm{~nm}$, where the influence of turbidity was still greater for the GSA II. It should be noted that at the wavelengths higher than $492 \mathrm{~nm}$, the difference $\mathbf{A}_{3}-\mathbf{A}_{2}$ no longer decreased, but increased. This phenomenon might be explainable in terms of two physical laws with opposite effects, that are brought into play during measurement in a turbid medium.

First, the Rayleigh law (11) affirms that the increase in absorbance with turbidity is inversely proportional to the fourth power of the wavelength. This is verified up to $492 \mathrm{~nm}$.

$$
I_{D}=K I_{0} \frac{n^{2}-n_{0}{ }^{2}}{n^{2}+2 n_{0}{ }^{2}} \frac{-N V^{2}}{\lambda_{0}{ }^{4}}
$$

$I_{D}:$ intensity of scattered radiation

$I_{0}$ : intensity of incident radiation

$\mathrm{V}$ : volume of particles

$\mathrm{N}$ : number

$\mathrm{K}$ : constant

$\mathrm{n}_{\mathrm{o}}$ : index of refraction in medium

$\mathrm{n}$ : index of refraction of the particles

Secondly, it is known that the light transmitted in a turbid medium decreases with increasing wavelength $(3,12,13)$. The measured absorbance thus increases. Above $492 \mathrm{~nm}$, this phenomenon becomes preponderant and may explain the rise in this curve (fig. 6) between 492 and $578 \mathrm{~nm}$. Such a rise was not noted for the Aminco $\mathrm{DW}_{2}$ instrument (fig. 5), perhaps because the position of the photomultiplier was specially designed for turbid solutions.

The values on the vertical axis, for the Beckman Di GT device (fig. 7), are higher than for the other two photometers, irrespective of the wavelength and the turbidity used. The second law, concerning transmitted light, may be of importance for this apparatus from wavelength $405 \mathrm{~nm}$ onwạds.

\section{Is the use of a blank sample necessary?}

The difference in absorbance $\mathbf{A}_{4}-\mathbf{A}_{2}$, which reflects the utility and the effectiveness of a blank sample, should be zero or close to it; this indicates that the influence of the turbidity has been effectively eliminated by the use of the blank. A general conclusion as to the effectiveness of using a blank sample cannot be established because each photometer or spectrophotometer has its own optical characteristics. The use of a blank sample for the tests on the Aminco (fig. 8) was ineffective: at $366 \mathrm{~nm}$, the residual absorbance, $\mathbf{A}_{4}-\mathbf{A}_{2}$, was $25 \%$ of the calculated, $\mathbf{A}_{3}-\mathbf{A}_{2}$.

The GSA II photometer behaved similarly; the residual absorbance reappeared weakly at $578 \mathrm{~nm}$ (fig. 9).

The residual absorbance, $A_{4}-A_{2}$ found with the Beckman DB GT spectrophotometer (fig. 10) was higher than for the othe- instruments: it was on average 0.05 absorbance unit. It seems that this instrument does not eliminate the effect of turbidity below a threshold peculiar to itself.

It appears that all the instruments studied require the use of a blank sample at all wavelengths, especially for highly turbid samples. As it is difficult or impossible to select samples according to their level of turbidity before assaying them, it follows that the blank sample should be used systematically.

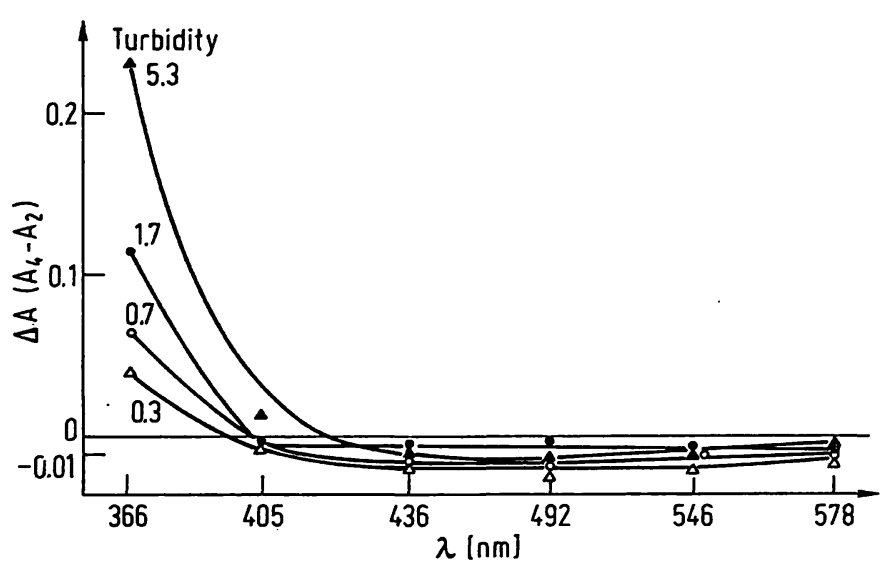

Fig. 8. Aminco $\mathrm{DW}_{2}$ - Use of the blank sample. On the vertical axis is shown the difference in absorbance, $\mathbf{A}_{4}-\mathbf{A}_{2}$, which represents the residual absorbance after elimination of that of the blank sample, as a function of wavelength.

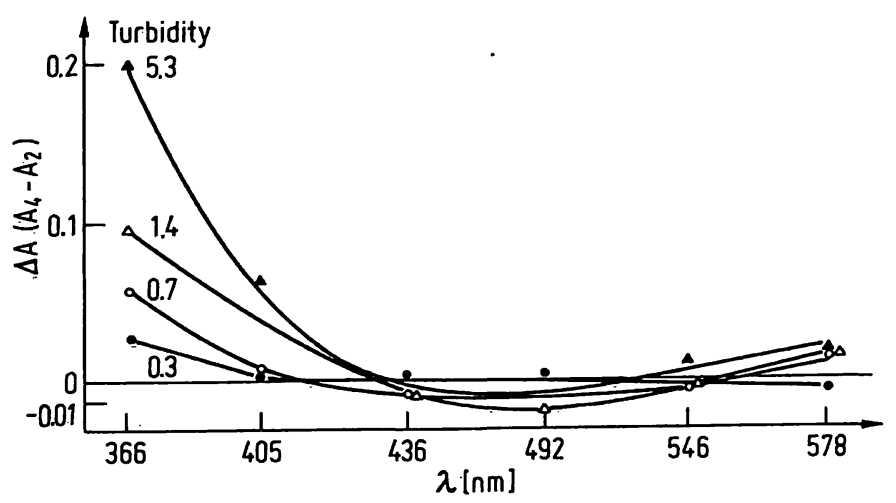

Fig. 9. Greiner GSA II - Use of the blank sample. On the vertical axis is shown the difference in absorbance, $A_{4}-A_{2}$, which represents the residual absorbance after elimination of that of the blank sample, as a function of wavelength. 


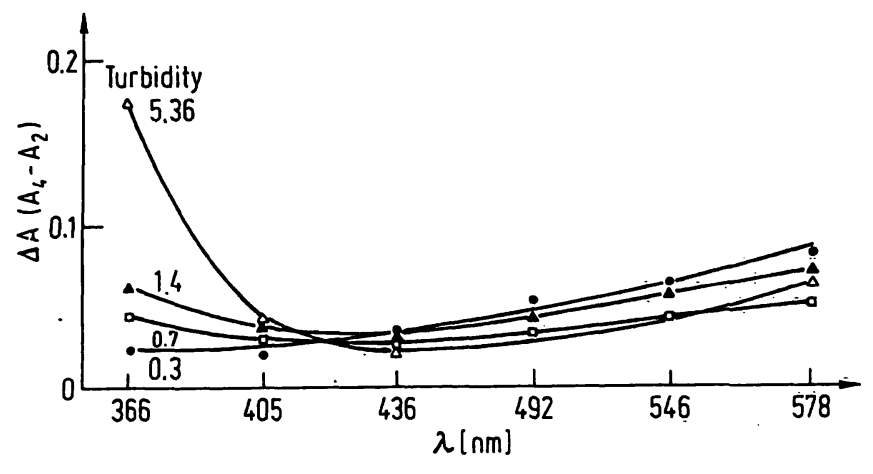

Fig. 10. Beckman DB GT - Use of the blank sample.

On the vertical axis is shown the absorbance difference, $\mathbf{A}_{4}-\mathbf{A}_{2}$, which represents the residual absorbance after elimination of that of the blank sample, as a function of wavelength.

\section{Applications}

A study was made of the usefulness of a blank sample for assaying glucose by the glucose oxidase/peroxidase (GOD/POD) method.

The tests were made on about 100 presumably healthy patients who came to the Centre de Médecine Préventive for a medical checkup.

The plasma glucose of each individual was assayed four times:

- on the Greiner GSA II automatic spectrometer;

- by the glucose hexokinase method;

- by the glucose oxidase/peroxidase (GOD/POD) method;

- and manually, following the procedures of the automatic GOD/POD method. The tests were made with and without a blank sample.

The absorbance values of the blank samples are noted in table $3 \mathrm{a}$. The reading was at $546 \mathrm{~nm}$.

Tab. 3a. Absorbance values of the blank samples. $\mathrm{n}=$ number $\mathrm{S}=$ Standard Deviation

\begin{tabular}{llll}
\hline GOD POD manual method & $\begin{array}{l}\mathrm{n} \\
\text { population } \\
\mathrm{P}_{1}\end{array}$ & Average & $\mathrm{S}$ \\
\hline Blank sample absorbance & 100 & $\begin{array}{l}0.004 \mathrm{dA} \\
\text { (or 0.128 } \\
\text { mmol/1 } \\
\text { of glucose) }\end{array}$ & 0.002 \\
\hline
\end{tabular}

\section{Results}

The population of plasma samples was divided according to turbidity:

Population $\mathrm{P}_{1}<$ turbidity $0.6 \leqslant$ Population $\mathrm{P}_{2}$

100 patients About 11 patients

For population $P_{1}$, the average absorbance of the blank samples (containing plasma and buffer) was $0.004 \mathrm{ab}$ sorbance units \pm 0.002 ; a high dilution ratio, $I / 125$, was used.

0.004 absorbance units expressed as a glucose concentration represents $0.128 \mathrm{mmol} / 1$ (table $3 \mathrm{a}$ ). This value was found for population $P_{1}$, and the average of the measurements carried out manually was compared with and without a blank sample (tab. 3b). The average of the differences was $0.134 \mathrm{mmol} / \mathrm{l}$. The method without a blank sample presents a positive interference due to the turbidity of the samples.

Population $\mathrm{P}_{\mathbf{2}}$ was about $10 \%$ of the patients. Each case is presented individually. There was good correlation between the glucose hexokinase and the glucose oxidase tests in the manual method with a blank (tab. 4a). On the other hand, if the GOD/POD without a blank is compared with the two methods using a blank, there was a systematic average shift of $0.478 \mathrm{mmol} / 1$. Patient samples of very high turbidity are relatively rare at the Centre de Médecine Préventive (tab. $4 \mathrm{~b}$ ), but such samples are much more common in the hospital environment. The difference noted between the methods with and without a blank corresponds to the modification of absorbance brought about by the turbidity of the sample itself.

\section{Conclusion}

For each type of instrument it appears necessary to determine, as a method is evaluated or improved, the influence of the turbidity of the sample and the accuracy of the assay. It must also be verified that no reagent modifies this turbidity, either diminishing it, as does EDTA, or increasing it. Examining the results of the analysis of the correlation between certain parameters could lead to some erroneous interpretations. The influence of the turbidity of a plasma sample is such that it is necessary to utilize a blank sample. Our results apply only to the spectrophotometers studied here. It is certain that the problem must be taken into account for each type of apparatus.

Tab. 3b. Study of the importance of the blank sample. Application to the assay of glucose for Population $P_{1}\left(\mathbb{P}_{1}\right.$ have turbidity $<0.6)$.

$\mathrm{n}=$ number $(\mathrm{s})=$. significant $\quad \mathrm{S}=$ Standard Deviation

\begin{tabular}{llllll}
\hline GOD POD manual method & $\mathrm{n}$ & population $\mathrm{P}_{1}$ & $\begin{array}{l}\text { Average } \\
\mathrm{mmol} / 1\end{array}$ & $\begin{array}{l}\text { Average of the } \\
\text { differences }\end{array}$ & $\mathrm{S}$ \\
\hline Measurement without blank sample & 92 & 5.78 & 0.134 & 0.07 & 18.94 (s.) \\
Measurement with blank sample & 92 & 5.65 & & $\ldots$ \\
\hline
\end{tabular}


Tab. 4a. Study of the importance of turbidity on the results of glucose assay for Population $P_{2}\left(P_{2}\right.$ have turbidity $\left.>0.6\right)$.

\begin{tabular}{lllll}
\hline $\begin{array}{l}\text { Patient No. } \\
\left(\mathbf{P}_{2}\right)\end{array}$ & $\begin{array}{l}\text { Turbidity of plasma } \\
\text { sample absorbance units }\end{array}$ & $\begin{array}{l}\text { Hexokinase } \\
\text { (mmol/1) }\end{array}$ & $\begin{array}{l}\text { GOD/PAP } \\
\text { with blank } \\
(\mathrm{mmol} / \mathrm{l})\end{array}$ & $\begin{array}{l}\text { GOD/PAP } \\
\text { without blank } \\
(\mathrm{mmol} / \mathrm{l})\end{array}$ \\
\hline 200990 & 0.97 & 5.27 & 5.26 & 5.73 \\
201006 & 1.37 & 5.15 & 5.13 & 5.68 \\
201008 & 0.80 & 5.80 & 5.81 & 6.15 \\
201011 & 1.07 & 4.39 & 4.66 & 5.09 \\
201029 & 0.62 & 5.10 & 5.18 & 5.53 \\
201033 & 0.71 & 5.44 & 5.54 & 5.89 \\
201039 & 0.90 & 4.65 & 4.87 & 5.27 \\
201125 & 1.15 & 5.86 & 5.68 & 6.14 \\
\hline
\end{tabular}

Tab. 4 b. Special cases: test on the three methods on the GSA II. The blank sample absorbance was evaluated manually.

\begin{tabular}{llllll}
\hline $\begin{array}{l}\text { Patient No. } \\
\left(\mathbf{P}_{2}\right)\end{array}$ & $\begin{array}{l}\text { Turbidity of plasma } \\
\text { sample absorbance units }\end{array}$ & $\begin{array}{l}\text { Absorbance of blank } \\
\text { sample }\end{array}$ & $\begin{array}{l}\text { Hexokinase } \\
(\mathrm{mmol} / \mathrm{l})\end{array}$ & $\begin{array}{l}\text { GOD/PAP } \\
\text { with blank } \\
\text { (mmol/l) }\end{array}$ & $\begin{array}{l}\text { GOD/PAP } \\
\text { without blank } \\
(\mathrm{mmol})\end{array}$ \\
\hline 201600 & 3.12 & $0.066=2.1 \mathrm{mmol} / 1$ & 5.27 & 5.74 & 7.55 \\
201603 & 21.00 & $0.117=3.74 \mathrm{mmol} / 1$ & 5.33 & 5.80 & 9.63 \\
201637 & 0.92 & $0.011=0.3 \mathrm{mmol} / 1$ & 6.05 & 6.08 & 6.24 \\
\hline
\end{tabular}

\section{References}

1. Trinder, P. (1969) Ann. Clin. Biochem. 6, 24.

2. Lauber, K. (1965) Z. Klin. Chem. Klin. Biochem. 3, 96-99.

3. Gautschi, M. \& Richterich, R. (1973) Z. Klin. Chem. Klin. Biochem. 11, 139-146.

4. Picon, M., Guillot, M. \& Renault, H. (1946), Manipulations de physique biologique. Ed. CDV, 23-50.

5. Weber, R. (1959), Pharm. Biol. 12, 29-32.

6. Borst, A., De Jong, E. B. M. \& Weijden, A. H. (1973), Clin. Chim. Acta, 55, 113-119.

7. Vanderlind, R. E., Richards, A. H. \& Kowalski, P. (1975)

Clin. Chim. Acta, 61, 39-46.

8. Rice, E. W. (1976), Clin. Biochem. 9, 4.
9. Morell, S. A. \& Doumas, B. T. (1973), Clin. Chem. 19, 783-785.

10. Manet, L., Martin, J., Lamy, C., Barba, M. \& Beaugirard, S. (1962), Ann. Biol. Clin. 5-6, 441-470.

11. Métais, P. (1977) Biochimie Clinique. Ed. Simep, p. 170.

12. Weber, M. R. (1967), Photométrie des milieux troubles. Monit. Pharmacies, 774.

13. Diffusion de la lumière introduction théorique. Publication interne de la Société d'Instruments de Contrôle et d'Analyses.

14. Frings, C. S., Muscat, V. I. \& Waldrop, N. T. (1976) Clin. Chem. 22, 101-102.
Dr. G. Hubsch

Laboratoire du Centre de Médecine Préventive

2 , ave. du Doyen J. Parisot

F-54500 Vandoeuvre-lès-Nancy 
.

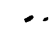

